\title{
Hjerneødem etter status epilepticus
}

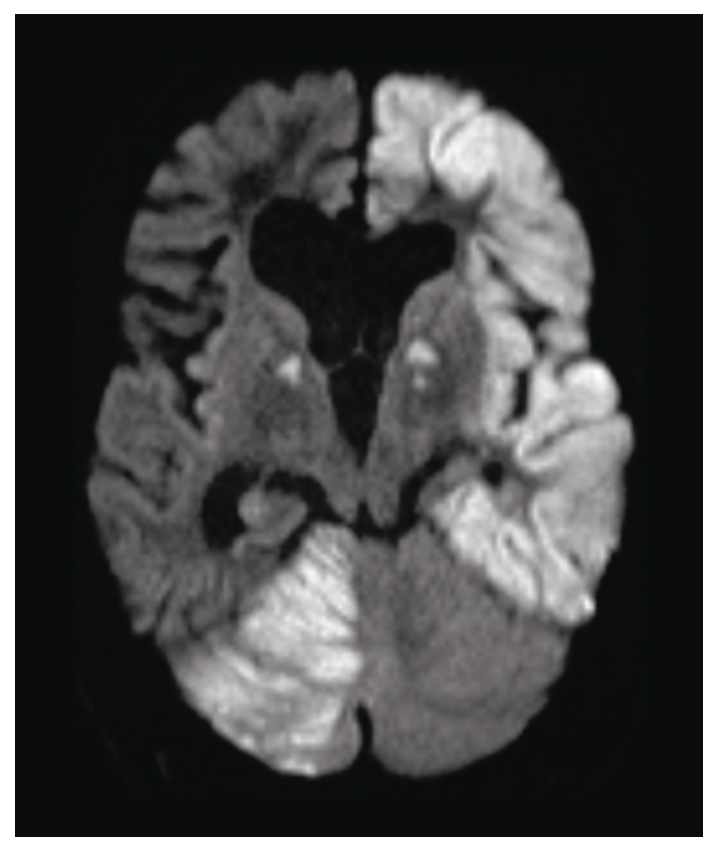

En mann i 20-årene med antatt posttraumatisk epilepsi etter en alvorlig hodeskade noen år tidligere ble innlagt i lokalsykehus etter et epileptisk krampeanfall av minst 30 minutters varighet. Ved innkomst var pasienten somnolent, ga lite verbal kontakt og hadde høyresidig hemiparese som ble oppfattet som en forbigående lammelse etter epilepsianfallet (Todds parese). CT caput ga mistanke om ødem i venstre hemisfære. For å forebygge nye anfall ble det startet opp med lave doser levertiracetam ved innkomst.

To dager senere fikk pasienten kortvarige fokale anfall i serie med hodedreining mot høyre og høyresidige rykninger. Anfallene ble forsøkt kupert med valproat $\mathrm{i}$ bolus og infusjon - uten hell. Pasienten ble lagt i barbituratnarkose og overflyttet til universitetssykehus, hvor man hevet sedasjonen påfølgende dag. Han forble imidlertid komatøs, og det ble derfor gjort MR-undersøkelse av hjernen. Den viste utbredte områder med redusert diffusjon som tegn på cytotoksisk ødem kortikalt i venstre storehjernehemisfære, i basalganglier, i thalamus bilateralt samt i høyre lillehjernehemisfære. Pasienten ble på ny sedert for å avlaste hjernen og forebygge videre utvikling av hjerneødemet. Etter noen dager med intensivbehandling våknet han gradvis opp etter at sedasjonen ble stoppet. MR-kontroll viste noe tilbakegang av forandringene.

Cerebralt ødem i forbindelse med epileptiske anfall er beskrevet flere ganger i litteraturen, men prevalensen er ukjent. I en amerikansk studie som inkluderte 86 pasienter med status epilepticus, hadde ti forandringer på MR caput som ble oppfattet som følgetilstand av det aktuelle epilepsianfallet. Hos fem pasienter ble det funnet redusert diffusjon kortikalt, forenlig med cytotoksisk ødem, og én hadde samtidig forandringer i kontralaterale lillehjerne, slik som hos vår pasient (1).

Cytotoksisk ødem oppstår ved svikt i den energikrevende natrium-kalium-pumpen i cellemembranene hvor vann strømmer inn i cellene, som svulmer opp (2). Akutt iskemi er en typisk årsak til dette, men ved status epilepticus kan man tenke seg at ødemet utløses av ubalanse mellom energitilgang og energibehov i nevronene (1).

Hos pasientene med cytotoksisk ødem i den amerikanske studien var status epilepticus foranlediget av hypoksi eller cerebral hypoperfusjon (1). Retrospektivt kan man mistenke at vår pasient hadde inadekvat oksygenering av hjernen under sitt langvarige krampeanfall i hjemmet før han ble innlagt. Ødemet kan så ha blitt forsterket av en ny langvarig periode med serieanfall på lokalsykehuset.

MR-forandringene på bildet illustrerer nevroanatomien med det fokale utgangspunktet i venstre storhjernehemisfære. Signalene forplanter seg til thalamus og basalganglier bilateralt og til kontralaterale lillehjernehemisfære via kryssede og ukryssede aksonale baner.

Pasientens pårørende har gitt samtykke til at artikkelen blir publisert.
Kristin Wesnes kristin.wesnes@gmail.com Kathrine K. Lian Nevrologisk avdeling

\section{Kjell Arne Kvistad}

Avdeling for radiologi og billeddiagnostikk

St. Olavs hospital

Kristin Wesnes (f. 1981) er lege i spesialisering i nevrologi.

Forfatter har fylt ut ICMJE-skjemaet og oppgir ingen interessekonflikter.

Kathrine K. Lian (f. 1980) er spesialist i nevrologi og overlege.

Forfatter har fylt ut ICMJE-skjemaet og oppgir ingen interessekonflikter.

Kjell Arne Kvistad (f. 1960) er dr.med., spesialist i radiologi og seksjonsoverlege i nevroradiologi.

Forfatter har fylt ut ICMJE-skjemaet og oppgir ingen interessekonflikter.

Litteratur

1. Milligan TA, Zamani A, Bromfield E. Frequency and patterns of MRI abnormalities due to status epilepticus. Seizure 2009; 18: 104-8.

2. Liang D, Bhatta S, Gerzanich V et al. Cytotoxic edema: mechanisms of pathological cell swelling Neurosurg Focus 2007; 22: E2. 